\title{
STUDY ON THE FEATURES OF GEOGRAPHY/SCIENCES INTERACTIVE MULTIMEDIA LEARNING ACTIVITIES (IMLA) IN A DIGITAL TEXTBOOK
}

\author{
OANA-RAMONA ILOVAN \\ Babeş-Bolyai University, Faculty of Geography, Department of Regional Geography and Territorial \\ Planning, Cluj-Napoca, Romania, e-mail: ilovanoana@yahoo.com
}

\author{
SANDA-RAVECA BUZILĂ \\ "Iacob and Ioachim Mureşanu" Secondary School Rebrișoara, Bistrița-Năsăud County, Romania, e-mail: \\ sandabuzila@yahoo.com
}

\section{MARIA ELIZA DULAMĂ}

Babeş-Bolyai University, Faculty of Psychology and Sciences of Education, Department of Exact Sciences Didactics, Cluj-Napoca, Romania, e-mail: dulama@upcmail.ro

\section{LEON BUZILĂ}

"Iacob and Ioachim Mureșanu" Secondary School, Rebrișoara, Bistrița-Năsăud County, Romania, e-mail: leonbuzila@yahoo.com

(Received: November 2017; in revised form: January 2018)

\begin{abstract}
The aim of our research was analysing the animated interactive multimedia learning activities (IMLA) with a Geography/Sciences contents, within the Mathematics and Environmental Exploration digital textbooks for the $2^{\text {nd }}$ grade, edited by the $C D$ PRESS Publishing House in 2014. We conceived an assessment grid focusing a series of features of the respective Geography/Sciences activities: animation type, clarity and relevance of the included images, unfolding speed of the images, manner of realising the unfolding (e.g. zooming), existence of marking (e.g. arrows) and the accordance between image and orally transmitted information (image-oral text simultaneity), information correctness, information load amount, information accessibility, didactic method used, number of tasks, stimulated cognitive processes, and activity duration.
\end{abstract}

Keywords: Geography education in the primary grades, assessment grid, elearning, educational animations 


\author{
O.-R. ILOVAN, S.-R. BUZILĂ, M.E. DULAMĂ, L. BUZILĂ
}

\title{
INTRODUCTION AND THEORETICAL APPROACH
}

Digital textbooks for Mathematics and Environmental Exploration were introduced in the Romanian education system for the $2^{\text {nd }}$ grade, beginning with the 2014-2015 school year. The digital textbook is a software product that one can use online or offline, using any type of technology, operation system and browser, independently from the e-Learning platforms (Vlada, 2014).

In these digital textbooks, there are diverse interactive multimedia learning activities (IMLA). In The Tender Book (2013), with the requirements that such digital textbooks should meet during the national competition, these IMLA are included into four categories: static, having a low degree of interactivity (drawings, photos, etc.); animated, that include animations and animated films over which the pupils have limited control by sequencing, running Play, Stop and Pause; interactive, which include educational elements with a high degree of interactivity (simulations, problem solving, educational games, etc.); complex that additionally offer a continuity of accumulation / competences acquired by the pupils for the entire use duration, from a conceptual perspective; they provide an immersive function of the continuos learning process through discovery. A digital textbook should have minimum 60 animated IMLA (AIMLA).

In scientific literature, didactic animations are considered tools making teachers' and pupils' work easier. Their components are the following: the contents (graphics, animation, sound, and text), the instructional design, and the programme management (Dulamă and Gurscă, 2006; Dulamă and Ilovan, 2007).

The aim of this research is to analyse the animated interactive multimedia learning activities (AIMLA) from the digital textbook of Mathematics and Environmental Exploration, for the $2^{\text {nd }}$ grade, CD PRESS Publishing House (authors: Iliana Dumitrescu, Nicoleta Ciobanu and Alina Carmen Birta), a textbook that Sanda Buzilă, the second author of this paper, used during classes after choosing it from the six textbooks approved by the Ministry to be used in the Romanian public education system. This textbook is available on $C D$ and on the platform of the Ministry of National Education, The National Centre for Assessment, at https://www.manuale.edu.ro/.

\section{MATERIAL AND METHOD}

The material of the research we realised in 2017 is represented by the AIMLA from the digital textbook of Mathematics and Environmental Exploration, for the $2^{\text {nd }}$ grade, CD PRESS Publishing House. 
For this analysis, we conceived an assessment tool. For each AIMLA, we analysed the identification data (title of the thematic unit, lesson title, IMLA title) and diverse features: animation type according to the nature of its components (drawings, photos, films), number of drawings/photos in an IMLA, duration of activity (seconds), speed of image rendering (imagine/second), image clarity, the modality of realising the dynamics (e.g. zoom in or out) and the existence of marking (for instance, through arrows), agreement between title and contents, between images and text, simultaneity image-oral text (image rendering in the same pace with the orally transmitted information), information correctness, image relevance, amount of information degree, information accessibility, the used didactic methods, number of tasks associated to a certain activity, the cognitive processes stimulated during the activity. We processed the data statistically and we systemised them in data tables.

\section{RESULTS AND DISCUSSIONS}

\section{The place of IMLA in the digital textbook}

This textbook is structured into two volumes of 63 pages each. The contents is organised into eight thematic units. In six (63\%) thematic units, the Mathematics content integrates adequately into the Geography/Sciences ones, while the other are integrated with content from other subjects (Table 1 ).

From the 88 lessons of this textbook, 17 have Geography/Sciences content (Table 1). In the Thematic Unit 5. We experiment, count and compute to 1,000, the authors integrated Geography/Sciences content, without any lessons in which this content prevails. The number of lessons with Geography/Sciences content differs from one thematic unit to another (1-6 lessons/thematic unit).

In the eight thematic units, there are 190 IMLA. Out of this, 93 activities are static, 61 are animated, and 36 are interactive. Each lesson has an average of two IMLA. For an efficient analysis, out of the 61 AIMLA (Table 1), we research only the IMLA for Geography/Sciences content lessons, and this means 38 IMLA (an average of 2.2 IMLA per lesson).

Table 1. IMLA within thematic units and lessons with Geography/Sciences content

\begin{tabular}{|l|l|l|l|l|}
\hline $\begin{array}{c}\text { Title of the } \\
\text { learning unit }\end{array}$ & \multicolumn{2}{|c|}{$\begin{array}{c}\text { Lessons with } \\
\text { Geography/Sciences content }\end{array}$} & \multicolumn{2}{c|}{$\begin{array}{c}\text { Animated IMLA with } \\
\text { Geography/Sciences content }\end{array}$} \\
\hline & No. & Title & Title & No. \\
\hline $\begin{array}{l}\text { U1. Let us } \\
\text { remember! }\end{array}$ & 1 & Earth Sciences & Water Circuit in Nature & 1 \\
\hline
\end{tabular}


O.-R. ILOVAN, S.-R. BUZILĂ, M.E. DULAMĂ, L. BUZILĂ

\begin{tabular}{|c|c|c|c|c|}
\hline \multirow{2}{*}{$\begin{array}{l}\text { U2. We count } \\
\text { and compute } \\
\text { to } 100, \\
\text { travelling } \\
\text { through the } \\
\text { Universe }\end{array}$} & \multirow[b]{2}{*}{4} & $\begin{array}{l}\text { The Earth. Day and } \\
\text { Night }\end{array}$ & $\begin{array}{l}\text { Day and Night, The } \\
\text { Seasons }\end{array}$ & \multirow[b]{2}{*}{6} \\
\hline & & $\begin{array}{l}\text { Planets of the Solar } \\
\text { System }\end{array}$ & $\begin{array}{l}\text { The Moon, The Solar } \\
\text { System, My Place in the } \\
\text { Universe, The Planets of } \\
\text { the Solar System }\end{array}$ & \\
\hline \multirow{2}{*}{$\begin{array}{l}\text { U3. We learn } \\
\text { to compute } \\
\text { quickly while } \\
\text { looking at the } \\
\text { environment }\end{array}$} & \multirow{2}{*}{2} & $\begin{array}{l}\text { Plants. Common } \\
\text { Features }\end{array}$ & $\begin{array}{l}\text { Evolution of a Plant, } \\
\text { Magnolia }\end{array}$ & \multirow{2}{*}{4} \\
\hline & & $\begin{array}{l}\text { Animals. Common } \\
\text { Features }\end{array}$ & $\begin{array}{l}\text { Animals. Features, } \\
\text { Breeding }\end{array}$ & \\
\hline \multirow{6}{*}{$\begin{array}{l}\text { U4. We } \\
\text { explore the } \\
\text { living } \\
\text { environments }\end{array}$} & \multirow{6}{*}{6} & $\begin{array}{l}\text { The North Pole. The } \\
\text { South Pole }\end{array}$ & $\begin{array}{l}\text { The North Pole and The } \\
\text { South Pole, The } \\
\text { Eskimos, Animals from } \\
\text { the Poles, The Seal, The } \\
\text { Penguin, The Polar Bear }\end{array}$ & \multirow{6}{*}{19} \\
\hline & & The Black Sea & The Black Sea & \\
\hline & & $\begin{array}{l}\text { The Lake. The Swamp. } \\
\text { The Pond }\end{array}$ & $\begin{array}{l}\text { The lake. The Swamp. } \\
\text { The Pond, The Frog }\end{array}$ & \\
\hline & & The Desert & $\begin{array}{l}\text { The Desert, The } \\
\text { Dromedary }\end{array}$ & \\
\hline & & The Danube Delta & $\begin{array}{l}\text { The Delta, Animals from } \\
\text { the Delta }\end{array}$ & \\
\hline & & The Forest & $\begin{array}{l}\text { The Forest, Animals } \\
\text { from the Forest, The } \\
\text { Fox, The Brown Bear, } \\
\text { The Hedgehog, The } \\
\text { Mushroom }\end{array}$ & \\
\hline \multirow{4}{*}{$\begin{array}{l}\text { U6. We learn } \\
\text { to compute } \\
\text { quickly, while } \\
\text { exploring the } \\
\text { landforms }\end{array}$} & \multirow{4}{*}{4} & $\begin{array}{l}\text { The Earth. Land, Air, } \\
\text { and the Atmosphere }\end{array}$ & The Living Planet & \multirow{4}{*}{8} \\
\hline & & Landforms & Landforms & \\
\hline & & Mountains and Hills & $\begin{array}{l}\text { The Mountain, Animals } \\
\text { from the Mountain, The } \\
\text { Hill, Animals from the } \\
\text { Hill }\end{array}$ & \\
\hline & & The Field & $\begin{array}{l}\text { The Field, Animals from } \\
\text { the Field }\end{array}$ & \\
\hline Total & 17 & & & 38 \\
\hline
\end{tabular}

\section{Quantitative and Qualitative Features of the IMLA}

Animation type according to the nature of its components (drawings, photos, and films). $97.3 \%$ of the AIMLA include a series of photos with 
audio presentation, with a rather uniform tonality, even monotonous, realised by a woman. These IMLA are similar to the slideshows realised in PowerPoint. $2.7 \%$ of the IMLA include drawings with an audio presentation. No AIMLA includes films.

Number of drawings/photos in the IMLA. The number of images in an IMLA varies from one to 13 . One IMLA includes one drawing, two IMLA include one photo each, and other two IMLA have 13 photos each. In total, all the IMLA have 254 photos (an average of 6.8 photos in an IMLA). We consider that using several photos in an IMLA makes it difficult for pupils to focus their attention on them, to understand, and to memorize them.

Duration of the IMLA. The duration of rendering the photos or the drawings in the IMLA varies from one multimedia activity to another. The longest duration is 70 seconds, the shortest is $4 \mathrm{~s}$, and the latter is too short to present the content. The average duration varies from one thematic unit to another, between $19.5 \mathrm{~s}$ and $30 \mathrm{~s}$. Duration varies according to the number of photos or drawings that it includes and depending on the volume of information presented. The duration below $70 \mathrm{~s}$ of an IMLA is appropriate to the $2^{\text {nd }}$ graders' attention focus duration.

Speed of rendering the photos and drawings. The fastest speed of rendering photos is of one photo at each $1.3 \mathrm{~s}$ (Table 2), and the slowest one is of one drawing or photo each $30 \mathrm{~s}$. In 14 IMLA, the speed is of one photo presented for 1-2 $\mathrm{s}$, and this speed is too fast for students to have time to notice the essential aspects and certain details that the respective photo captured. In order to analyse in depth a drawing or a photo it is necessary to pause the presentation.

Table 2. Typology and several quantitative features of IMLA

\begin{tabular}{|c|c|c|c|c|c|c|c|c|c|}
\hline \multirow{2}{*}{$\begin{array}{l}\text { Title of the } \\
\text { learning } \\
\text { unit }\end{array}$} & \multirow{2}{*}{$\begin{array}{l}\text { No. of } \\
\text { lessons }\end{array}$} & \multirow{2}{*}{$\begin{array}{l}\text { No. of } \\
\text { AIMLA }\end{array}$} & \multicolumn{2}{|c|}{ Type } & \multicolumn{2}{|c|}{ Number } & \multicolumn{2}{|c|}{ Duration } & \multirow{2}{*}{$\begin{array}{l}\text { Speed of } \\
\text { image } \\
\text { progress }\end{array}$} \\
\hline & & & $\begin{array}{c}\text { With } \\
\text { drawings }\end{array}$ & $\begin{array}{l}\text { With } \\
\text { photos }\end{array}$ & Drawings & Photos & $\begin{array}{l}\text { Total } \\
(\mathrm{s})\end{array}$ & $\begin{array}{l}\text { Average } \\
\text { (s) }\end{array}$ & \\
\hline $\begin{array}{l}\text { U1. Let us } \\
\text { remember! }\end{array}$ & 1 & 1 & 1 & - & 1 & - & $30 \mathrm{~s}$ & $30 \mathrm{~s}$ & $1 / 30 \mathrm{~s}$ \\
\hline $\begin{array}{l}\text { U2. We } \\
\text { count and } \\
\text { compute to } \\
100 \text {, } \\
\text { travelling } \\
\text { through the } \\
\text { Universe }\end{array}$ & 4 & 6 & - & 6 & - & 18 & $\begin{array}{r}160 \mathrm{~s} \\
\text { Min. } \\
4 \mathrm{~s} \\
\text { Max. } \\
37 \mathrm{~s}\end{array}$ & $26,6 s$ & $\begin{array}{r}\text { Max. } \\
1 / 30 s \\
\text { Min. } \\
1 / 3.44 s\end{array}$ \\
\hline $\begin{array}{l}\text { U3. We } \\
\text { learn to } \\
\text { compute } \\
\text { quickly } \\
\text { while } \\
\text { looking at } \\
\text { the environ- } \\
\text { ment }\end{array}$ & 2 & 4 & - & 4 & - & 30 & $\begin{array}{c}88 \mathrm{~s} \\
\text { Min. } \\
12 \mathrm{~s} \\
\text { Max. } \\
34 \mathrm{~s}\end{array}$ & $22 s$ & $\begin{array}{r}\text { Max. } \\
\text { 1/4.66s } \\
\text { Min. } \\
\text { 1/1.33s }\end{array}$ \\
\hline
\end{tabular}


O.-R. ILOVAN, S.-R. BUZILĂ, M.E. DULAMĂ, L. BUZILĂ

\begin{tabular}{|c|c|c|c|c|c|c|c|c|c|}
\hline $\begin{array}{l}\text { U4. We } \\
\text { explore the } \\
\text { living } \\
\text { environ- } \\
\text { ment }\end{array}$ & 6 & 19 & - & 19 & - & 134 & $\begin{array}{r}547 \mathrm{~s} \\
\text { Min. } \\
9 \mathrm{~s} \\
\text { Max. } \\
70 \mathrm{~s}\end{array}$ & $28,79 \mathrm{~s}$ & $\begin{array}{r}\text { Max. } \\
1 / 11.6 \mathrm{~s} \\
\text { Min. } \\
1 / 1.3 \mathrm{~s}\end{array}$ \\
\hline $\begin{array}{l}\text { U6. We } \\
\text { learn to } \\
\text { compute } \\
\text { quickly, } \\
\text { while } \\
\text { exploring } \\
\text { the } \\
\text { landforms }\end{array}$ & 4 & 8 & - & 8 & - & 72 & $\begin{array}{c}156 \mathrm{~s} \\
\text { Min. } \\
12 \mathrm{~s} \\
\text { Max. } \\
41 \mathrm{~s}\end{array}$ & $19.5 \mathrm{~s}$ & $\begin{array}{r}\text { Max. } \\
1 / 4.1 \mathrm{~s} \\
\text { Min. } \\
1 / 1.5 \mathrm{~s}\end{array}$ \\
\hline $\begin{array}{l}\text { Total } \\
\text { number }\end{array}$ & 17 & 38 & 1 & 37 & 1 & 254 & $\begin{array}{r}981 \mathrm{~s} \\
= \\
16.35 \\
\mathrm{~min}\end{array}$ & 26.48 & \\
\hline Average & & & $2.7 \%$ & $97.3 \%$ & $2.7 \%$ & 6.8 & & & \\
\hline
\end{tabular}

Image clarity in the IMLA. From analysing and assessing the 254 photos and drawings used in the IMLA, it appears that $85 \%$ of the photos have the adequate clarity and this favours being perceived by pupils, and implicitly, understanding the content. We assigned scores from 1 to 3 to the image clarity in the IMLA (1- small; 2- average; 3- big). The average score of 2.8 shows the good image clarity of the photos from the multimedia activities (Tables $3 a$ and $3 b$ ).

Realising the dynamics and existence of markings in the video type components. Although these IMLA are called animated, most of them are made up of static photos. Still, certain photos are expanded, diminished, rotated, and moved on the screen automatically, but this dynamic has a small role in having pupils perceive the content. To enable understanding and visualising certain details and essential features, in $5.3 \%$ of the AIMLA that we analysed, there were markings (arrows) that pointed to the place where a certain phenomenon took place (e.g. the water circuit in nature). The fact that in most AIMLA the authors did not use markings to show the places that the presenter refered to made it difficult for the user to realise the connection between image and its significance, and this issue was solved by the teacher, during classes.

Agreement between the title of the AIMLA and their content. In 34 of the IMLA (89.5\%), there is a good agreement between their title and content. For each activity, we assigned 1 to 3 points for the agreement degree. In three thematic units, for this agreement, we assigned the maximum score (an average of 3), and in other two, the average of 2-2.6 underlineed the need for revision. 
STUDY ON THE FEATURES OF GEOGRAPHY/SCIENCES IMLA IN A DIGITAL ...

Table 3a. Several features of animated IMLA, highly important for learning

\begin{tabular}{|c|c|c|c|c|}
\hline Title of learning unit & $\begin{array}{l}\text { Image } \\
\text { clarity } \\
1-3\end{array}$ & $\begin{array}{l}\text { Title- } \\
\text { contents } \\
\text { agreement } \\
1-3\end{array}$ & $\begin{array}{l}\text { Images- } \\
\text { oral text } \\
\text { agreement } \\
1-3\end{array}$ & $\begin{array}{l}\text { Images-oral } \\
\text { text } \\
\text { synchronism } \\
1-3\end{array}$ \\
\hline U1. Let us remember! & 2 & 3 & 3 & 3 \\
\hline $\begin{array}{l}\text { U2. We count and compute } \\
\text { to } 100 \text {, travelling through } \\
\text { the Universe }\end{array}$ & 2.5 & 2.6 & 2.3 & 2.1 \\
\hline $\begin{array}{l}\text { U3. We learn to compute } \\
\text { quickly, while looking at the } \\
\text { environment }\end{array}$ & 2.7 & 2 & 2.5 & 2.5 \\
\hline $\begin{array}{l}\text { U4. We explore the living } \\
\text { environments }\end{array}$ & 3 & 3 & 2.3 & 2.2 \\
\hline $\begin{array}{l}\text { U6. We learn to compute } \\
\text { quikly, while exploring the } \\
\text { landforms }\end{array}$ & 2.8 & 3 & 2.5 & 2.5 \\
\hline Average of total IMLA & 2.8 & 2.7 & 2.5 & 2.4 \\
\hline $\begin{array}{l}\text { IMLA observes the } \\
\text { requirements }(\%)\end{array}$ & $85 \%$ & $89.5 \%$ & $42.2 \%$ & $42.2 \%$ \\
\hline
\end{tabular}

Table 3b. Several features of animated IMLA, highly important for learning

\begin{tabular}{|l|r|r|r|r|}
\hline Title of learning unit & $\begin{array}{l}\text { Information } \\
\text { correctness } \\
1-3\end{array}$ & $\begin{array}{l}\text { Image } \\
\text { relevance } \\
1-3\end{array}$ & $\begin{array}{l}\text { Accessibility } \\
1-3\end{array}$ & $\begin{array}{l}\text { Information } \\
\text { amount } \\
1-3\end{array}$ \\
\hline U1. Let us remember! & 3 & 2 & 3 & 2 \\
\hline $\begin{array}{l}\text { U2. We count and } \\
\text { compute to 100, } \\
\text { travelling through the } \\
\text { Universe }\end{array}$ & 2.6 & 1.6 & 2.8 & 1.3 \\
\hline $\begin{array}{l}\text { U3. We learn to compute } \\
\text { quickly, while looking at } \\
\text { the environment }\end{array}$ & 3 & 2.7 & 3 & 1.1 \\
\hline $\begin{array}{l}\text { U4. We explore the living } \\
\text { environments }\end{array}$ & 3 & 2.3 & 2.8 & 1.1 \\
\hline $\begin{array}{l}\text { U6. We learn to compute } \\
\text { quikly, while exploring } \\
\text { the landforms }\end{array}$ & 2.9 & 2.2 & 2.94 & \\
\hline Average of total IMLA & $92.1 \%$ & $47.3 \%$ & $94.7 \%$ & $84.2 \%$ \\
\hline $\begin{array}{l}\text { IMLA observes the } \\
\text { requirements (\%) }\end{array}$ & & & & 3 \\
\hline
\end{tabular}




\section{O.-R. ILOVAN, S.-R. BUZILĂ, M.E. DULAMĂ, L. BUZILĂ}

Agreement between the images and the text in the AIMLA. In $42.2 \%$ of the IMLA, there is agreement between the image and the text exposed during the rendering of the images. In the IMLA from the first thematic unit Let us remember! there is maximum agreement between images and text (an average of 3), and in the other IMLA, the average of 2.3-2.5 underlines the need for revision.

Image-oral text simultaneity. We analysed whether during the exhibition of photos authors provided information about its content or whether the information provided in the respective moment referred to the aspects represented or not in the respective photos. In $42.2 \%$ of the IMLA, rendering the images is in agreement with the transmitted information. In most of the IMLA, there is no simultaneity between the image and the text exposed at the moment of rendering the respective photo, meaning that the oral text refers to other image than to the one on the screen and this makes pupils' understanding of information difficult and it does not enable learning. The average score (3) was assigned only to the first thematic unit Let us remember! The average of all the IMLA for this indicator is 2.4 and it is lower than the one that shows the title-content agreement and the agreement between the images and the text of the entire IMLA.

Correctness of the information in the IMLA. In $92.1 \%$ of the analysed IMLA, information, explanations and definitions are correct; only in two of the IMLA information is unclear and with some mistakes. In the IMLA from the three thematic units, the information is correct (an average of 3 ), and in the other, the average score for correctness is 2.6-2.7 and this underlines the need for revision.

Relevance of the drawings/photos from the IMLA. We analysed whether the photos and the drawings used are the most appropriate for illustrating the content of the approached topic. In $47.3 \%$ of the IMLA, the chosen images are relevant for the respective lesson. The images in the 38 IMLA have average relevance (2.28), therefore we concluded that the authors could change certain photos and drawings, could complete them, or could give up to some of them.

Accessibility of content in the IMLA. We analysed whether the photos, through the represented aspects and the content are appropriate for the pupils' level of understanding and knowledge. The average for the 38 AIMLA points out their high accessibility degree. $94.7 \%$ of the IMLA got the maximum score for accessibility.

Degree of information amount in the IMLA. The 1.15 average shows a low degree of information amount for the IMLA, and this is positive if we take into account pupils' age, knowledge, and understanding. $84.2 \%$ of the IMLA have a low degree of information amount and $15.8 \%$ have an average degree of information amount of the IMLA. 
The didactic methods used in the IMLA. Exposition and observation, which determine pupils' passive role (Ciascai, 2001, 2007; Dulamă, 2011, 2012; Magdaș, 2014), were used in all AIMLA. Through exposition, images were mostly associated with the informative text (definitions, enumerations, presenting facts, and diverse assertions). Authors used rarely the explanation method (10\%), although physical phenomena and biological and geographical processes required explanation, and even if pupils' age was small and their capacity of understanding was rather concrete than abstract.

Tasks associated with AIMLA. This textbook proposes a rather small number of tasks in the AIMLA with Mathematics content, and in the 38 AIMLA with Geography/Sciences content there are no such tasks associated with the audio-video material, neither in written, nor in audio format. In the specialty literature, researchers underlined the importance of questions and of the tasks proposed to pupils in order to increase learning efficiency (Ciascai, 2001, 2007; Dulamă, 2000; Dulamă and Roşcovan, 2007; Magdaș, 2014) and the necessity to offer feedback about their solutions (Dulamă and Ilovan, 2016).

Cognitive processes stimulated through AIMLA. For each IMLA, we analysed the cognitive processes stimulated to pupils because of watching it and listening to it. Because in all IMLA, the authors used the exposition method associated to images, they stimulated perception, representation, and memory. In $8 \%$ of the IMLA, thinking is stimulated through the explanation method, and in $16 \%$ of the IMLA imagination is stimulated, while in $21 \%$ of the IMLA the stimulated one is curiosity.

\section{CONCLUSIONS}

All the animated IMLA attached to the lessons with Geography/Sciences content from this digital textbook should determine little pupils' individual activity, without being necessary that an adult guides them. But these IMLA are structured as an information collection that is rather received as given than extracted or discovered through personal effort by the users, thus maintaining pupils' low interest and knowledge level. For conceiving them, authors used just some more or less relevant drawings and photos presented in slideshows and they used mostly expositive methods, not exploiting in an adequate manner the methods that the virtual learning environment provides (simulation, educational games, experiments, and tutorials).

Presenting the IMLA (i.e. slideshows) is clear, simple, and correct enough, with a logical structure of the transmitted messages. The animated IMLA have a small information amount and they take into account pupils' previous knowledge. The meaning of the text presented in the IMLA is clear, 


\section{O.-R. ILOVAN, S.-R. BUZILĂ, M.E. DULAMĂ, L. BUZILĂ}

easy to understand, the punctuation is justified, but sometimes the phrases become boring because of too many enumerations, and this induces boredom and diminishes the users' interest for the approached subject.

The author uses from time to time a leading idea, as a silver line, in order to raise the users' interest to study the text. Other times, the exposition style is sober, sometimes too sober for a child of that small age, with imprecise language, words being unable to stimulate pupils' thinking and emotions.

The illustration quality is adequate to the features of second graders, but there is disagreement between images and the orally transmitted information. The drawings are appropriate aesthetically and attractive, the multimedia resources have good quality and resolution, while the sound is also good. The graphical structure of the screens is functional and, followed in a coherent manner, allows the return to the previous learning activity. Certain ergonomic rules are observed and thus the easy rendering of electronic contents is ensured.

\section{References}

Ciascai, L. (2001). Introducere în didactica ştiinţelor. Didactica disciplinei "Ş̧tiinţe". Cluj-Napoca: Casa Cărţii de Ştiinţă.

Ciascai, L. (2007). Didactica ştiinţelor naturii. Cluj-Napoca: Casa Cărţii de Ştiinţă.

Dulamă, M.E. \& Gurscă, D. (2006). Instruirea asistată de calculator în lecţia de geografie. In M.E. Dulamă, O.-R. Ilovan, F. Bucilă, Tendinţe actuale în predarea şi învătarea geografiei/Contemporary Trends in Teaching and Learning Geography (2) (pp. 246-258). Cluj-Napoca: Editura Clusium.

Dulamă, M.E. \& Ilovan, O.-R. (2007). Study on Didactic Animation Use in Learning Geography. Studia Universitas Babeş-Bolyai. Psychologia-Paedagogia, LII(2), 71-80.

Dulamă, M.E. \& Ilovan, O.-R. (2016). How Powerful is Feedforward in University Education? A Case Study in Romanian Geographical Education on Increasing Learning Efficiency. Educational Sciences: Theory \& Practice (ESTP), Kuram ve Uygulamada Eğitim Bilimleri (KUYEB), 16(3), 827-848.

Dulamă, M.E. \& Roşcovan, S. (2007). Didactica geografiei. Chișinău: Editura BONS OFFICES.

Dulamă, M.E. (2000). Strategii didactice. Cluj-Napoca: Editura Clusium.

Dulamă, M.E. (2011). Geografie şi didactica geografiei pentru învăţământul primar şi preşcolar. Cluj-Napoca: Presa Universitară Clujeană.

Dulamă, M.E. (2012). Ştiinţe şi didactica ştiinţelor pentru învăţământul primar şi preşcolar. Cluj-Napoca: Presa Universitară Clujeană. 
Dumitrescu, I., Ciobanu, N. \& Birta, A. (2014). Matematică şi explorarea mediului. Manual pentru clasa a II-a. Bucureşti: Editura CD PRESS.

Magdaș, I.C. (2014). Didactica matematicii pentru invaţămantul primar sji pres,colar: actualitate și perspective. Cluj-Napoca: Presa Universitară Clujeană.

National Assessment and Examination Center, Ministry of National Education and Scientific Research of Romania (2013). Caiet de sarcini. Manuale școlare pentru clasele I și a II-a (Tender Book for first and second grades textbooks). Retrieved 17 August 2017, from http://media.hotnews.ro/media_server1/document-2014-04-23-170931640 -caiet-sarcini-manuale-scolare-clasa.pdf

Vlada, M. (2014). Manuale digitale, o premieră în România - despre confuzii și clarificări. Lucrările Conferinţei de Învăţământ Virtual (Procedings of CNIV) (pp. 37-44). București: Editura Universităţii din București. Retrieved 17 August 2017, from https://www.scribd.com/doc/243699383/Proceedings-ofCNIV-2014 